\title{
The Use of Personal Protective Equipment for Reducing Accidental Risk on Board
}

\author{
Iksiroh El Husna \\ Nautical Department \\ Merchant Marine Polytechnic \\ Semarang \\ Semarang, Indonesia \\ iksirmahfud@yahoo.co.id
}

\author{
Anissofiah Azise \\ Nautical Department \\ Merchant Marine Polytechnic \\ Semarang \\ Semarang, Indonesia \\ anissofiah1987@gmail.com
}

\author{
Sarifuddin \\ Technical Department \\ Merchant Marine Polytechnic \\ Semarang \\ Semarang, Indonesia \\ sarifuddin.kemenhub@yahoo.com
}

\begin{abstract}
Ships have been preferable transportation modes in archipelagic countries like Indonesia because of their capability of transporting heavy loads. Indonesia has a great potential in maritime business and employment. However, accidental rate on board is also very high. Therefore, human behaviors during the activities on the sea become determining factors. This study discussed the use of PPE by student officers during accidents on board. The study used a quantitative method by questioner dissemination to 60 student officers (30 from nautical study and $\mathbf{3 0}$ from engineering study) from different grades. The study found that 47 respondents had suffered accident related to PPE, 11 related to improper PPE, 6 accidents due to the absence of helmet, 18 accidents due to the absence of safety shoes, 4 accidents due to the absence of goggle, and 8 accidents due to the absence of glove, resulting in a broken finger accident. This study recommended the company to socialize the PPE required by the law to prevent accident at work.
\end{abstract}

Keywords: PPE, work accident, seafarer

\section{INTRODUCTION}

Ships are effective transportation modes because of their capability to carry heavy loads on board. Jason [1] writes that ships contribute more than $80 \%$ to global maritime trade. Such great contribution allows sea transports to open many employment opportunities. The important factor that affects the maritime employment is force of nature or weather.

Safety at work for institutions/ companies becomes a key to success. A company is deemed successful when it is able to achieve zero accident during the work. The high accidental rate at work is due to human factors.

\section{LITERATURE REVIEW}

According to Suma'mur [2] occupational safety is the primary means of preventing accidents, disability and death as a result of workplace accidents. Occupational safety involves all processes of production and distribution of goods and services. Occupational safety is a gateway for labor security. The purpose of work safety is to protect the safety of workers for the welfare of life and increase productivity, ensure the safety of every other person who is in the workplace and the maintenance of production resources and can be used safely and efficiently by Suwardi
[3]. Occupational safety for employees is guaranteed by law number 1 of 1970 and law number 25 of 1997 concerning worker protection and safety. The purpose of health and occupational safety is to protect workers, coworkers, worker's families, consumers and others who may be affected by work environment conditions.

According to Suma'mur [4], occupational health for workers / community workers to obtain the highest degree of health, whether physical, or mental, or social, with preventive and curative efforts, against diseases / disorders health caused by factors of work and work environment, as well as against common diseases. According to WHO / ILO in Hebbie [5], occupational health to improve and maintain the highest degree of physical, mental and social health for workers in all types of work, prevention of employee health problems caused by working conditions, protection for workers in his work from the risk due to factors that harm health and maintenance of workers in a work environment that is adjusted to the physiological and psychological conditions. In summary, this is the adjustment of work to humans and every human being to their work or position.

Accidents due to work are unforeseen, undesirable events and cause loss of both life and property by Soehatman [6], whereas according to Suma'mur [7], workrelated accidents are accidents related to work at the company, meaning that work accidents occur caused by work or when carrying out work.

Heinrich [8] in which unsafe act contributes the most accidents (88\%). Dupont in Heinrich, even states 96\%. In the other words, $88-96 \%$ of the accident can be prevented by improving worker behaviors.

According to Hinze [9] accident does not always cause physical injuries because it also affects material and equipment damages. De Reamer [10] adds that accident is a situation that occurs beyond one's plan. Accident at work occurs directly by unsafe act and unsafe condition. Furthermore, it occurs due to human and environmental factors. Human factors relate to physical, mental, and psychological competencies, lacking knowledge and skills, as well as improper motivation. Whereas, the environmental factors deal with physical factors (noise, radiation, lighting, climate, etc.) and chemicals (dust, lead steam, smoke, gas, etc.). In principle, the accident at work 
can be repented by administrative and technical approaches to the use of the PPE.

An accident may reduce company performance because it reduces worker productivity rate. Small investment with big reward is proposed by Health, Safety, and Environment (HSE) professionals in the management of PPE by Anonymous [11]. Many fatal accidents at work are caused by the improper use of the PPE, such an accident that occurred on October 7, 2017 on a ship while doing ship crane maintenance, a ship crew fell and was injured in the head due to the use of an imperfect helmet (MARS Report). One of the crew was hit by a winch because he did not wear safety shoes. It was a fatal accident, which led to finger amputation by Syafii [12]. Another accident at Belize' flagged MV Madona in Singapore revealed that the victims did not wear gloves during the accident by Masriadi [13]. Overall, the on board accident rate in Indonesia was still considered higher than that of other countries due to lacking knowledge about the PPE by Saut [14].

Personal Protective Equipment (PPE) is safety equipment is the last effort to protect themselves to minimize dangers. According to Sabir [15], PPE is a tool that must be used when working as needed to maintain the safety of the workers themselves and those around them. According to Husni [16] to avoid the risk of workplace accidents, employees are required to use PPE. Sedarmayanti [17] states that one of the security measures is to provide safe equipment including clothing/ special work protection to protect employees when carrying out their work. The Law No. 1 of 1970 concerning Work Safety [18] and the law No. 25 of 1997 concerning protection and safety workers [19] to mandates companies and workers (seafarers) to implement the use of PPE, to guarantee and protect the safety of every workforce and others in the workplace. So that every company or workplace such as a ship must provide PPE and always provide socialization and supervision to their workers about the use of PPE by Tadesse [20] and McLaughlin [21]. The company has an obligation to provide training on the use of PPE. An important element of training according to OSHA is ensuring that workers understand the proper way to use PPE, inspect, maintain and maintain it for maximum sustainable protection by Nussbaum [22]. Including the company's obligation to clean work clothes by Kelsch [23]. The obligation to use PPE is strengthened by Minister of Manpower and Transmigration Regulation No. Per.08 / Men / VII / 2010 [24] concerning personal protection. According to OSHA in the United States every year thousands of workers face and eye injuries because they do not use PPE by Elliot [25]. The basic principles of OSHA for PPE are self-assessments of potential hazards faced by workers by Anonymous [26], [27], [28] which discusses the prevention of work accidents on ships and ports related to the use of PPE. According to Ridley [29] and Suma'mur [30], effective self-protection equipment must: (1) In accordance with the hazards faced, (2) made of material that will withstand these hazards, (3) suitable for people who will use it, (4) does not interfere with the work of the operator on duty, (5) has a very strong construction, (6) do not interfere with other self-protection equipment that is being used simultaneously, and (7) does not increase the risk to the wearer. Personal protective equipment must also: (1) Be provided free of charge, (2) given one per person for one tool or if not, must be cleaned after use, (3) only used according to its designation, (4) maintained in good condition, (5) repaired or replaced if damaged, and (6) stored in a suitable place when not in use.

PPE (Personal Protective Equipment) that must be used includes tools that can protect all parts of the body from head to toe. This includes a helmet, glasses, mask, ear plug ear muff, gloves, wear pack, shoes. In certain jobs requiring specific personal protective equipment such as chemical tankers that have very dangerous loads will be different from ordinary charged vessels such as cargo ships or container ships.

Personal Protective Equipment can be divided into 3 groups, namely

Head Protective Equipment including: Helmet, Safety Glass, Mask, Respirator, Ear Plugs and Ear Muffs.

\section{A. Safety helmet}

Helmet or Protective Cap is used to make head protection from exposure to hazards such as falling objects or exposure to electrical hazards. The use of a Protective Helmet must match the head circumference until it is comfortable and efficient to protect it. There are 3 types of helmet based on their protection on electricity, namely:

1) General Type Helmet $(G)$ that can protect the head from bumping and falling objects and reduce exposure to danger of low-voltage electricity to 2. 200 Volts

2) Electrical Type Helmet (E) that can protect the head from bumping and falling objects and reduce exposure to electrical hazards with high voltage up to 2. 200 Volts

3) Conductive Type Helmet (C) which can only protect the head from bumping and falling objects but does not protect the head from exposure to electrical current hazards.

\section{B. Protective Glasses (Safety Glass)}

Protective Goggles are tools used to make eye protection from the danger of jumping sharp objects, dust, small particles, reduce the dazzling light and splashes of chemicals. Protective Glasses are divided into 2 types, namely:

1) Safety Spectacles, in the form of general glasses and can only protect the eyes from the danger of jumping sharp objects, dust, small particles and reduce the dazzling light.

2) Safety Goggles, Glasses that have a shape attached to the face, eyes can be protected from the danger of splashing chemicals, smoke, steam, dust and sharp objects.

\section{Ear Plugs}

Earplugs or Ear Plugs are used to make hearing aids protect the ears from high intensity. Using Ear Plug, Tone Intensity can be reduced to $10 \sim 15 \mathrm{~dB}$. Ear Plugs are 
generally used by workers who work in areas that have high machine tones.

\section{Ear Muffs}

Ear Muffs or Ear Muffs are the tools used to protect hearing devices from high Tone Intensity. Ear Muffs can reduce tone intensity to $20 \sim 30 \mathrm{~dB}$. Ear Muffs are divided into Head Bands and Ear Cups made of foam pads to protect the outer ear (earlobe). Ear Muffs are often used by Engineers and Generator Technicians.

\section{E. Mask}

That is the tool used to protect respiratory equipment such as the nose and mouth from possible hazards such as soldering smoke, dust and mild chemical odors. Masks are generally made of cloth or paper.

\section{F. Respirator}

The respirator is a device used to protect respiratory equipment such as the nose and mouth from possible hazards such as soldering smoke, the smell of chemicals, dust, steam, gas and mist particles and Fume particles. Respirators are often used by Soldering Machine Technicians, Painting Operators and other chemical systems.

1) Body Protective Equipment includes: Apron (Apron): That is body protection equipment from chemical splashes and hot temperatures.

2) Protective limbs one of them, namely: Protective Shoes (Safety Shoes / Boot), Gloves (Hand Gloves). an Equipment used to make hand protection from chemical contact, scratches or hand wounds due to touch with sharp and sharp objects. Gloves are generally used in chemical preparation systems, installation of rather sharp components, heating systems and so on. Some types of gloves include one of the following:

a) Cotton Gloves, used to make hand protection from scratches, cuts and light cuts.

b) Leather Gloves (Leather Gloves), are used to make hand protection from scratches, cuts and light cuts.

c) Rubber Gloves (Rubber Gloves), are used to make hand protection from contact with chemicals such as Oil, Oil, Adhesives and Grease.

d) Electrical Gloves, are used to make hand protection from contact with electric currents that are low to high voltage. b. Protective Shoes (Safety Shoes / Boot) equipment used to protect the foot from falling objects, sharp objects such as glass or pieces of steel, chemical solutions and electricity. Protective shoes are fitted with steel at the end with rubber band [30].

\section{ReSEARCH METHOdology}

This study used respondents of student officers at the Merchant Marine Polytechnic Semarang in June 2019. Research population consisted of 60 students (30 from nautical study and 30 from engineering study) from different grades (V-I). Data analysis took place after questioners had been returned and in-depth interviews had been performed.

\section{RESUlTS AND DISCUSSION}

The study result show that 60 respondents, found that 47 respondents had experienced accidents on board related to the PPE. Of these accidents, 11 due to improper protective devices (unsuitable shoes, causing slip and sprain or broken arm, leg, even back bone), 6 accidents occurred because they did not wear helmet, causing head injury and headache, 18 accidents occurred because they did not wear safety shoes, causing broken toes, 4 accidents occurred because they did not wear goggle during chipping, causing eye injury, and 8 accidents occurred because they did not wear safety gloves, causing broken fingers.

When observing the findings, the use of PPE is very important for the prevention of workplace accidents. From the interviews, there were several obstacles related to PPE, including: (1) Incomplete PPE inventory, (2) applying nonstandardized devices, (3) some PPE are broken, and (4) not properly used. So that it can cause work accidents. For that according to the mandate of the Law, the company must be sufficient the needs of the crew about PPE and always socialize the crew about how to use the PPE. Likewise, the crew must obey the laws and regulations of the company in preventing accidents by using PPE onboard.

\section{CONCLUSIONS AND RECOMMENDATIONS}

The results of the study that the occurrence of work accidents resulting from: (1) Incomplete PPE inventory, (2) applying non-standardized devices, (3) some PPE are broken, and (4) PPE is not properly used and some people do not use the PPE. For this reason, the company must always facilitate the adequacy and completeness of PPE, and socialize the use of PPE to prevent work accidents. Seafarers must obey to use PPE to prevent work accidents onboard.

Socialization on prospective seafarers at merchant marine polytechnic and educational institutions is very important, so the seafarers know and understand the importance of using PPE (Personal Protective Equipment).

\section{REFERENCES}

[1] Janson, E. Ballast Management, Seagull, Norway, 2005.

[2] Suma'mur, P.K, Safety and Prevent Prevention (in Indonesian). Hadji Masagung, Jakarta. 1986.

[3] Suwardi, Daryanto, K3LH Practical Guidelines (Occupational Safety and Health and the Environmental) (in Indonesian). Gava Media, Jogjakarta. 2018.

[4] Suma'mur, P.K, Company and Health Working (in Indonesian). Jakarta: CV Haji Masagung. 1998.

[5] Hebbie, Adzim, Understanding, Legal Basis and Scope of Occupational Health (in Indonesian). K3 Basics, Jakarta. 2015.

[6] Soehatman, Ramli. OHSAS 18001 Occupational Safety and Health Management System (in Indonesian). Jakarta. Dian Rakyat. 2010

[7] Suma'mur, P.K, Occupational Safety and Accident Prevention (in Indonesian). Jakarta: PT. Gunung Agung. 1989.

[8] Heinrich, H.W. Industrial Accident Prevention. Vermont Amerika. 1931.

[9] Hinze, JW, Construction Safety Practice Hall Inc, New Jersey, USA. 1977. 
[10] De Reamer, R, Modern Safety Practice, John Willey, New York. 1958.

[11] Anonymous. Management must understand cost-benefit of PPE, ISEA says. Professional Safety :Des Plaines Vol 47(8). (Aug 2002):1.

[12] Safii, Two Toes are Amputated by a Working Accident (in Indonesian), Liputan BMI, Madiun. 2017.

[13] Masriadi, Working Accident in Sea, ABK from Suriah is Evacuated (in Indonesian). Flash the Ministry of Komeninfo, Kompas.com, Augst 23th 2017.

[14] Saut, P.D. The Number of Working Accidents RI Increased to 123 thousand cases in 2017 (in Indonesian). Detik Finance, Bali. 2017.

[15] Sabir, Muhammad. Applying Health Procedures Module (in Indonesian). http://www.wordpress.com/.../modul-menerapkanprosedur-kesehata.doc. 2009.

[16] Husni, Lalu, Indonesian Employment Law (in Indonesian). Jakarta: PT. Raja Grafindo Persada. 2003.

[17] Sedarmayanti, Human Resources and Work Productivity (in Indonesian). Mandar Maju, Bandung. 2009.

[18] Law No.1 in 1970 concerning Work Safety(in Indonesian). Jakarta.

[19] Law No.25 in 1997 concerning Labor Protection and Safety (in Indonesian).

[20] Tadesse, S. et al. 2016. Utilization of personal protective equipment and associated factors amongtextile factory workers at Hawassa Town, Southern Ethiopia. Journal of Occupational Medicine and ToxicologyVol 11(6). Ethiopia.

[21] McLaughlin, Jennifer. 1999. Who Pays for Personal Protective Equipment?.OH \& S Canada : Don Mills Vol. 15, (Jul/Aug 1999): 2223.

[22] Julie, Nussbaum. 2000. Effective Training: Covering the Base.Occupational Health \&Safety ; Waco Vol. 69(12), (Dec 2000): $52-56+$.

[23] Kelsch, Noel, RDHAP. 2010. Personal Protective Clothing. RDH ; Tulsa (Jul 2010); 82-84.

[24] Minister of Manpower and Transmigration Regulation Number PER.08/MEN/VII/2010 concerning Personal Protective Equipment (in Indonesian). 2014. Jakarta.

[25] Elliot, Fred. 2003. Effective Use of PPE. Occupational Health \&Safety : Waco Vol. 72, Iss. 11, (Nov 2003): 76-78

[26] Anonymous. 1994. Safety Gets Personal. Small Business Reports Vol. 19, Iss. 11, (Nov 1994): 22. New York.

[27] Anonymous. 1994. Personal Protective Equipment and OSHA. The CPA Journal Vol 64 (10). (Okt 1994): 9. New York

[28] Anonymous, 1994. An ILO code of practice. Second (revised) edition. Geneva, 1996. xiv + 194 pp. Appendices, index. 27.50 Swiss francs. ISBN 92-2-10945

[29] Ridley, John, 2009. Safety and Health Work: Iktisar (3rd Edition). Jakarta: Erlangga (in Indonesian).

[30] Suma'mur, P.K, 2013. Hygiene Company and Health Work (HIPERKES) (2nd Edition) Jakarta: Sagung Seto (in Indonesian). 